\title{
Melatonin Effect on Immature Mouse Testicular Tissues, Vitrified-Thawed With Different Cryoprotectant Media
}

\author{
Mohammadreza Gholami ${ }^{1}$; Ghasem Saki ${ }^{2, *}$; Masoud Hemadi ${ }^{3}$; Ali Khodadadi ${ }^{4}$; Javad \\ Mohammadiasl $^{5}$ \\ ${ }^{1}$ Razi Herbal Medicines Research Center, Lorestan University of Medical Sciences, Khorramabad, IR Iran \\ ${ }_{2}^{2}$ Physiology Research Center, School of Medicine, Ahvaz Jundishapur University of Medical Sciences, Ahvaz, IR Iran \\ ${ }^{3}$ Fertility, Infertility and Perinatology Research Center, School of Medicine, Ahvaz Jundishapur University of Medical Sciences, Ahvaz, IR Iran \\ 4 . \\ 5 Department of Medical Genetics, School of Medicine, Ahvaz Jundishapur University of Medical Sciences, Ahvaz, IR Iran \\ *Corresponding author: Ghasem Saki, Physiology Research Center, School of Medicine, Ahvaz Jundishapur University of Medical Sciences, Ahvaz, IR Iran. Tel: +98-9166181685, Fax: \\ +98-6133335399, E-mail: ghasemsaki@yahoo.com
}

Received: June 16, 2014; Accepted: December 26, 2014

Background: Freezing of the immature testis tissue and then its transplantation can be considered a major step in fertility preservation for young boys with cancer.

Objectives: The objective of this study was to investigate the antioxidant effects of melatonin on histological structure of seminiferous tubules that were vitrified-thawed with different cryoprotectant media.

Materials and Methods: Male mice were randomly assigned to one of 10 experimental groups. Testes of 6-day-old BALB/c male mice pups were extracted and vitrified-thawed with different vitrification media with melatonin and without melatonin. Then, their testes were stained with haematoxylin-eosin.

Results: The result showed that supplementation of glycerol based media with melatonin has reduced injury to histological structure of seminiferous tubules in the 6-day-old male BALB/c mice pups testes $(\mathrm{P}=0.004)$.

Conclusions: It seem that melatonin due to its antioxidant properties, if added to glycerol based media, reduces the harmful effects of freezing-thawing process, and protects seminiferous tubules histological structure from oxidative injury.

Keywords: Mouse; Testis; Melatonin; Vitrification

\section{Background}

Cell transplantation and testicular grafting of small pieces of testicular tissue from a living donor to a receiver are two new tools that may be used in the future for treatment of infertile men. This technique allowed the study and manipulation of various aspects of spermatogenesis (1-5). Transplantation of fresh testicular cells or tissues is not always possible. Thus, the ability to preserve testicular tissue cells appears to be necessary for future use. Testes contain spermatogonial stem cells that are capable of proliferation and differentiation. Effective preservation of testes structure may allow them to resume normal proliferation (1-5). Cryopreservation of animal and human testicular cells has been done successfully, but too little attention has been paid to structure of testicular tissue during cryopreservation. Testicular tissue cryopreservation can be performed in cases that sperm cryopreservation is not possible. Preservation of testicular tissue used in children rescued from cancers such as neuroblastoma, lymphoma, Hodgkin disease, osteoarthritis sarcoma, Ewing's sarcoma, rhabdomyosarcoma, Wilms' tumor and non-Hodgkin lymphoma (1-5).

Spermatogenesis in adolescence may be impaired following radiotherapy and chemotherapy. There are different vitrification protocols for cryopreservation of immature testicular tissue but fine structure and cell viability of testes have not been preserved. Several studies examined pieces of frozen testes or testicular cell suspension using glycerol, ethylene glycol, dimethyl sulfoxide, and propanediol, but none were able to maintain high performance quality of spermatogonial stem cells (6). Genetic defects in the embryo vitrification have also created concerns similar to what is happening in slow freezing (7). Recently, supplementation of freezethaw media with antioxidants such as vitamin E, ascorbic acid, and selenium are considered. Another studies showed that the number of apoptotic cells increases in the vitrification solution on the first day of the thawing $(8,9)$. Many studies have been done to reduce vitrification cryoinjury. Recently, researchers have suggested

Copyright @ 2015, Ahvaz Jundishapur University of Medical Sciences. This is an open-access article distributed under the terms of the Creative Commons Attribution-NonCommercial 4.0 International License (http://creativecommons.org/licenses/by-nc/4.0/) which permits copy and redistribute the material just in noncommercial usages, provided the original work is properly cited. 
that supplementation of vitrification and thawing media with antioxidants may reduce cryoinjury (10-13). In another study, it was reported that supplementation vitrification and thawing solution of Dimethyl sulfoxide (DMSO) 15\% and ethylene glycol (15\%) with melatonin did not protect testicular tissue from injury (14). Melatonin is small biological molecule that is secreted in the pineal gland and other organs e.g., retina and testis (15-17). Effects of melatonin are studied in many regulatory functions of cells such as immune response, cell signaling, protecting fatty acids from oxidation and nuclear DNA from damage, controlling tumor growth and inhibiting cell proliferation, oncostatic action, anti-apoptotic effect on many normal cells, enhancing apoptosis in the tumor cells and significant anti-aging properties (15-29). The raised question was whether adding melatonin on other cryoprotectant media, based on glycerol, DMSO, ethylene glycol or mixture of them, can reduce cryoinjury.

\section{Objectives}

The study aimed to investigate the antioxidant effects of melatonin on histological structure of seminiferous tubules that are vitrified-thawed with different cryoprotectant media.

\section{Materials and Methods}

All experiments were performed in accordance with the principles of laboratory animal care. A total of 50, 6-day-old BALB/c male mice pups were obtained from physiology research center. Mice were euthanized by excessive doses of ketamine $\mathrm{HCl}(80 \mathrm{mg} / \mathrm{kg})$ and xylazine (10 mg/kg) (Pharmacia and Upjohn, Erlangen, Germany) in accordance with the protocols approved by the Ahvaz Jundishapur University Medical Science Animal Care and Use Committee. Male mice were randomly assigned to one of ten experimental groups. Testes of 6-day-old BALB/c male mice pups were extracted and vitrifiedthawed according to Table 1 . Samples after thawing were fixed with bouin's fixative. After 24 hours fixation, samples processed and stained with hematoxylin-eosin staining. Results of treated group with melatonin and control group (untreated group) were compared with Mean-Whitney U test and all groups were compared with Kruskal-Wallis H Test by SPSS 16.

\section{Results}

Tissue sections after vitrification using hematoxylineosin staining were studied and analyzed according to Milazzo et al. method (30). The blind evaluation of tissue sections was done by specialists. Statistical analysis of comparing seminiferous epithelium glycerol based vitrification media supplemented with melatonin (group 7) to the control group (group 8) was significant $(\mathrm{P}=0.004)$ (Figures 1 and 2). Statistical analysis of comparing seminiferous epithelium ethylene glycol based vitrification media supplemented with melatonin (group 1) with control group (group 2 ) was not significant $(P=0.226)$. Statistical analysis of comparing seminiferous epithelium ethylene glycol and glycerol based vitrification media supplemented with melatonin (group 3 ) to the control group (group 2) was not significant $(\mathrm{P}=0.529)$. Statistical analysis of comparing seminiferous epithelium DMSO and glycerol based vitrification media supplemented with melatonin (group 5) to the control group (group 6 ) was not significant $(P=0.529)$. Statistical analysis of comparing seminiferous epithelium DMSO based vitrification media supplemented with melatonin (group 9) to the control group (group 10) was not significant ( $\mathrm{P}=$ 0.529 ). All statistical analyses were done according to $\mathrm{Mi}$ lazzo et al. method (30)

\begin{tabular}{|c|c|c|c|c|c|c|}
\hline & Sucrose, 0.5 M & Ethylene Glycol & DMSO & Glycerol & FBS 20\% & Melatonin $100 \mu \mathrm{g} / \mathrm{mL}$ \\
\hline Group 1 & + & 40 & - & - & + & + \\
\hline Group 2 & + & 40 & - & - & + & - \\
\hline Group 3 & + & 7.5 & - & 7 & + & + \\
\hline Group 4 & + & 7.5 & - & 7 & + & - \\
\hline Group 5 & + & - & 7.5 & 7 & + & + \\
\hline Group 6 & + & - & 7.5 & 7 & + & - \\
\hline Group 7 & + & - & - & 15 & + & + \\
\hline Group 8 & + & - & - & 15 & + & - \\
\hline Group 9 & + & - & 15 & - & + & + \\
\hline Group 10 & + & - & 15 & - & + & - \\
\hline
\end{tabular}

a Abbreviations: DMSO, Dimethyl sulfoxide; and FBS, Fetal Bovine Serum.

b Data are presented as (\%). 

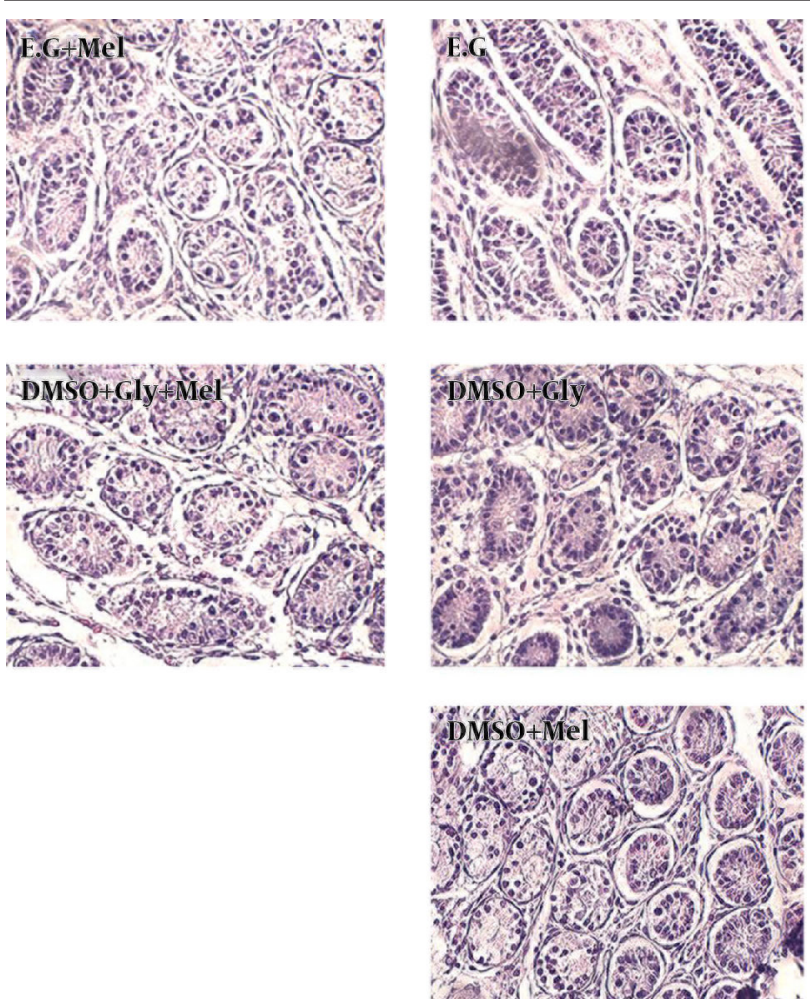
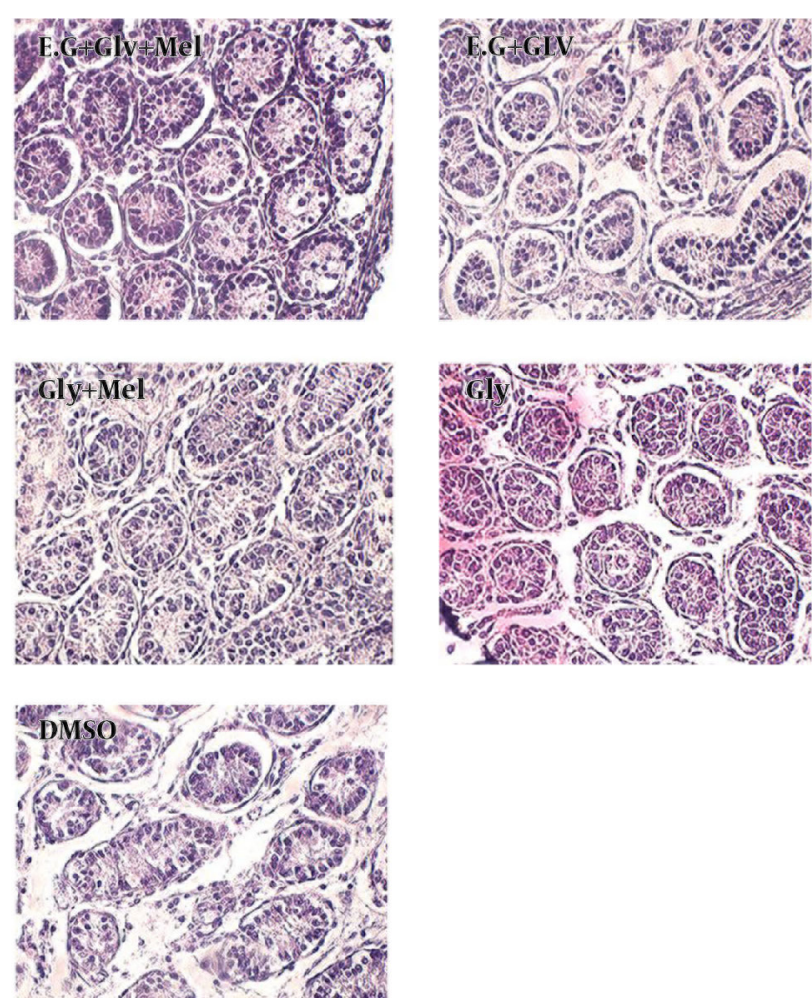

Testicular tissue that Vitrified-thawed with glycerol based media, supplemented with melatonin, showed the least amount of damage.

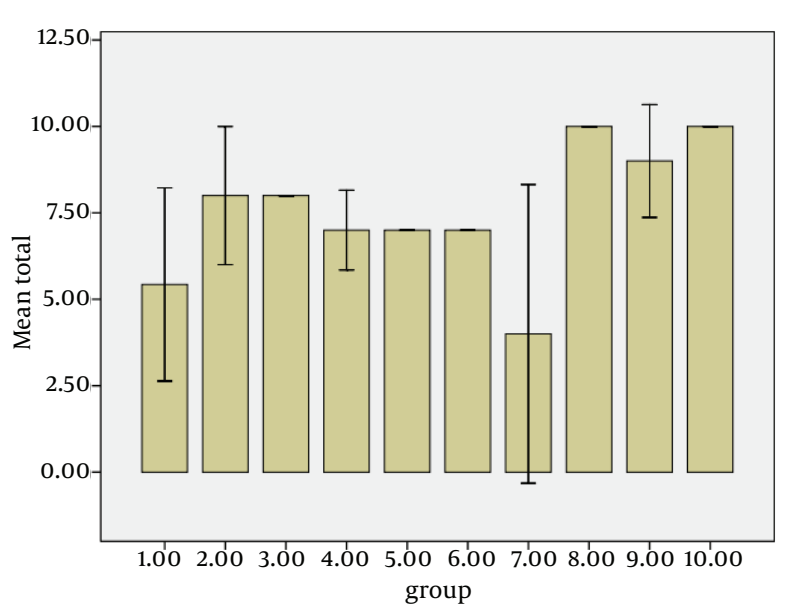

Figure 2. Results (Seminiferous Epithelium) of Treated Group With Melatonin and Control Group (Untreated Group)

\section{Discussion}

Oxidative stress is a critical factor in the death of animal tissues during the vitrification process. Spermatogonial stem cells and testis tissues are exposed to multiple stresses during the vitrification process $(31,32)$. Choosing a cryoprotectant approved by all authors for freezing cells had not been realized yet; however, many researchers have recently done extensive researches about choosing best cryoprotectant for vitrification. Vitrification processes differ from species to species due to the nature of their tissues and thus require optimization for different animal tissues. Melatonin is anti-apoptotic and antioxidant, which is secreted from the pineal gland. In a previous study, it was demonstrated that supplementation of vitrified-thawed media, DMSO and ethylene glycol plus sucrose, with melatonin did not protect testicular tissue from injury (14). DMSO, which is used during cryopreservation in routine laboratory tasks, has a lot of toxic effects. Researchers recently proposed that DMSO has antioxidant activity (33). Researchers recently showed that supplementation of vitrified-thawed media with ethylene glycol or dimethyl sulfoxide or a mixture of ethylene glycol and dimethyl sulfoxide causes fewer toxic effects on the cryopreserved mesenchymal stem cells (34). In this study, supplementation of glycerol vitrification media with melatonin showed fewer toxic effects on the cryopreserved immature testicular tissue. Uchendu et al. (35) recently showed that supplementation of cryopreservation media, DMSO based, with melatonin enhances the recovery of cryopreserved shoot tips of American elm.

Recently Succu et al. (36) has shown that supplementation of post warming media with melatonin enhances efficiency of vitrified ovine embryos. They showed that 
supplementation post warming media with high concentration of melatonin $\left(10^{-3}\right)$ had toxic effect on vitrified ovine embryos but supplementation post warming media with low concentration $\left(10^{-9}\right)$ of melatonin may have beneficial effects on development of vitrified ovine embryos (36). In this study, supplementation of vitrification media, DMSO based, with melatonin did not protect testicular tissue from injury.

Taken together, it can be said that supplementation of vitrification media, glycerol based, with melatonin had better effect on reducing testicular tissue injury while using melatonin in other environments of freezingthawing, e.g. DMSO based, ethylene glycol based, is less effective in reducing the damage caused vitrification. Supplementation of glycerol based vitrification media with melatonin reduces testicular tissue injury in the vitrification process.

\section{Acknowledgements}

This study was approved (grant number PRC-91) by the Physiology Research Center. Authors appreciate Ahvaz Jundishapur University of Medical Sciences, Ahvaz, IR Iran for the financial support.

\section{References}

1. van den Berg H, Furstner F, van den Bos C, Behrendt H. Decreasing the number of MOPP courses reduces gonadal damage in survivors of childhood Hodgkin disease. Pediatr Blood Cancer. 2004;42(3):210-5.

2. Lee SJ, Schover LR, Partridge AH, Patrizio P, Wallace WH, Hagerty $\mathrm{K}$, et al. American Society of Clinical Oncology recommendations on fertility preservation in cancer patients. J Clin Oncol. 2006;24(18):2917-31.

3. Mitchell RT, Saunders PT, Sharpe RM, Kelnar CJ, Wallace WH. Male fertility and strategies for fertility preservation following childhood cancer treatment. Endocr Dev. 2009;15:101-34.

4. Wallace WHB, Anderson RA, Irvine DS. Fertility preservation for young patients with cancer: who is at risk and what can be offered? Lancet Oncol. 2005;6(4):209-18.

5. Green DM, Kawashima T, Stovall M, Leisenring W, Sklar CA, Mertens AC, et al. Fertility of male survivors of childhood cancer: a report from the Childhood Cancer Survivor Study.J Clin Oncol. 2010;28(2):332-9.

6. Orwig KE, Schlatt S. Cryopreservation and transplantation of spermatogonia and testicular tissue for preservation of male fertility. J Natl Cancer Inst Monogr. 2005(34):51-6.

7. Mazur P. Equilibrium, quasi-equilibrium, and nonequilibrium freezing of mammalian embryos. Cell Biophys. 1990;17(1):53-92.

8. Curaba M, Verleysen M, Amorim CA, Dolmans MM, Van Langendonckt A, Hovatta $\mathrm{O}$, et al. Cryopreservation of prepubertal mouse testicular tissue by vitrification. Fertil Steril. 2011;95(4):1229-34 e1.

9. Curaba M, Poels J, van Langendonckt A, Donnez J, Wyns C. Can prepubertal human testicular tissue be cryopreserved by vitrification? Fertil Steril. 2011;95(6):2123 e9-12.

10. Ahmad R, Haldar C. Effect of intra-testicular melatonin injection on testicular functions, local and general immunity of a tropical rodent Funambulus pennanti. Endocrine. 2010;37(3):479-88.

11. Harms C. Melatonin is protective in necrotic but not in caspasedependent, free radical-independent apoptotic neuronal cell death in primary neuronal cultures. FASEB J. 2000;14(12):1814-24.

12. Succu S, Berlinguer F, Pasciu V, Satta V, Leoni GG, Naitana S. Melatonin protects ram spermatozoa from cryopreservation injuries in a dose-dependent manner. J Pineal Res. 2011;50(3):310-8.
13. Dominguez-Rebolledo AE, Fernandez-Santos MR, Bisbal A, RosSantaella JL, Ramon M, Carmona M, et al. Improving the effect of incubation and oxidative stress on thawed spermatozoa from red deer by using different antioxidant treatments. Reprod Fertil Dev. 2010;22(5):856-70.

14. Gholami M, Saki G, Hemadi M, Khodadadi A, Mohammadi-asl J. Supplementation vitrified-thawed media with melatonin do not protecting immature mouse testicular tissue from vitrifiedthawed induced injury. Asian J Anim Vet Adv. 2012;7:940-9.

15. Fildes JE, Yonan N, Keevil BG. Melatonin-a pleiotropic molecule involved in pathophysiological processes following organ transplantation. Immunology. 2009;127(4):443-9.

16. Hardeland R, Cardinali DP, Srinivasan V, Spence DW, Brown GM, Pandi-Perumal SR. Melatonin--a pleiotropic, orchestrating regulator molecule. Prog Neurobiol. 2011;93(3):350-84.

17. Zawilska JB, Skene DJ, Arendt J. Physiology and pharmacology of melatonin in relation to biological rhythms. Pharmacol Rep. 2009;61(3):383-410.

18. Hemadi M, Abolhassani F, Akbari M, Sobhani A, Pasbakhsh P, Ahrlund-Richter L, et al. Melatonin promotes the cumulus-oocyte complexes quality of vitrified-thawed murine ovaries; with increased mean number of follicles survival and ovary size following heterotopic transplantation. Eur J Pharmacol. 2009;618(13):84-90.

19. Gholami M, Saki G, Hemadi M, Khodadadi A, Mohammadi-asl J. Melatonin improves spermatogonial stem cells transplantation efficiency in azoospermic mice. Iran J Basic Med Sci. 2014;17(2):93-9.

20. Hemadi M, Zargar M, Sobhani A, Sobhani A. Assessment of morphological and functional changes in neonate vitrified testis grafts after host treatment with melatonin. Folia Morphol (Warsz). 2011;70(2):95-102.

21. Ahmad R, Haldar C. Melatonin and androgen receptor expression interplay modulates cell-mediated immunity in tropical rodent Funambulus pennanti: an in-vivo and in-vitro study. Scand $J$ Immunol. 2010;71(6):420-30.

22. da Silva CM, Macias-Garcia B, Miro-Moran A, Gonzalez-Fernandez L, Morillo-Rodriguez A, Ortega-Ferrusola C, et al. Melatonin reduces lipid peroxidation and apoptotic-like changes in stallion spermatozoa. J Pineal Res. 2011;51(2):172-9.

23. Martin-Renedo J, Mauriz JL, Jorquera F, Ruiz-Andres O, Gonzalez P, Gonzalez-Gallego J. Melatonin induces cell cycle arrest and apoptosis in hepatocarcinoma HepG2 cell line. J Pineal Res. 2008;45(4):532-40.

24. Millan-Plano S, Piedrafita E, Miana-Mena FJ, Fuentes-Broto L, Martinez-Ballarin E, Lopez-Pingarron L, et al. Melatonin and structurally-related compounds protect synaptosomal membranes from free radical damage. Int J Mol Sci. 2010;11(1):312-28.

25. Radogna F, Cristofanon S, Paternoster L, D'Alessio M, De Nicola $\mathrm{M}$, Cerella $\mathrm{C}$, et al. Melatonin antagonizes the intrinsic pathway of apoptosis via mitochondrial targeting of Bcl-2.J Pineal Res. 2008;44(3):316-25.

26. Radogna F, Paternoster L, Albertini MC, Accorsi A, Cerella C, D'Alessio M, et al. Melatonin as an apoptosis antagonist. Ann N Y Acad Sci. 2006;1090:226-33.

27. Radogna F, Paternoster L, Albertini MC, Cerella C, Accorsi A, Bucchini A, et al. Melatonin antagonizes apoptosis via receptor interaction in U937 monocytic cells. J Pineal Res. 2007;43(2):154-62.

28. Reiter RJ, Tan DX, Manchester LC, Paredes SD, Mayo JC, Sainz RM. Melatonin and reproduction revisited. Biol Reprod. 2009;81(3):445-56.

29. Zhao Y, Qi LW, Wang WM, Saxena PK, Liu CZ. Melatonin improves the survival of cryopreserved callus of Rhodiola crenulata. J Pineal Res. 2011;50(1):83-8.

30. Milazzo JP, Vaudreuil L, Cauliez B, Gruel E, Masse L, Mousset-Simeon $\mathrm{N}$, et al. Comparison of conditions for cryopreservation of testicular tissue from immature mice. Hum Reprod. 2008;23(1):17-28.

31. Gholami M, Saki G, Hemadi M, Khodadadi A, Mohamma-di-Asl J. Effect of Melatonin on the Expression of Apoptotic Genes in Vitrified-thawed Spermatogonia Stem Cells Type A of 6-Day-Old Mice. Iran J Basic Med Sci. 2013;16(8):906-9.

32. Gholami M, Hemadi M, Saki G, Zendedel A, Khodadadi A, Mohammadi-Asl J. Does prepubertal testicular tissue vitrification influ- 
ence spermatogonial stem cells (SSCs) viability? J Assist Reprod Genet. 2013;30(10):1271-7.

33. Sanmartin-Suarez C, Soto-Otero R, Sanchez-Sellero I, MendezAlvarez E. Antioxidant properties of dimethyl sulfoxide and its viability as a solvent in the evaluation of neuroprotective antioxidants. J Pharmacol Toxicol Methods. 2011;63(2):209-15.

34. Balci D, Can A. The assessment of cryopreservation conditions for human umbilical cord stroma-derived mesenchymal stem cells towards a potential use for stem cell banking. Curr Stem Cell
Res Ther. 2013;8(1):60-72.

35. Uchendu EE, Leonard SW, Traber MG, Reed BM. Vitamins C and E improve regrowth and reduce lipid peroxidation of blackberry shoot tips following cryopreservation. Plant Cell Rep. 2010;29(1):25-35.

36. Succu S, Pasciu V, Manca ME, Chelucci S, Torres-Rovira L, Leoni GG, et al. Dose-dependent effect of melatonin on postwarming development of vitrified ovine embryos. Theriogenology. 2014;81(8):1058-66. 